\section{Oliver Earl Benson}

From his matriculation in 1929 until his retirement in 1980, Oliver Benson's name was associated with political science at the University of Oklahoma. He was a among a select number of university faculty to attain national stature.

George Lynn Cross Research Professor Emeritus Oliver Earl Benson died January 26, 1999, at the age of 87. Professor Benson taught in the department of political science at the University of Oklahoma from 1936 to 1980 , specializing in international relations and methodology. He earned both bachelor's and master's degrees from Oklahoma and earned the doctorate from the Graduate Institute of International Studies at the University of Geneva in 1936. He directed the Bureau of Government Research from 1962 to 1969 and was chair of the Oklahoma department 1946-51 and 1959-62. In 1967, he was named George Lynn Cross Research Professor, the first to be so named in the department.

Oliver Benson was active in the American Political Science Association and the Southwestern Social Science Association, serving the latter as president in 1970-71. In 1995, Professor Benson was named Oklahoma Political Scientist of the Year by the Oklahoma Political Science Association, which he had helped to found. He was a member of American Association of University Professors and served as secretary of that organization. He also was a member of American Society of International Law and American Academy of Political and Social Sciences. He was editor of Southwestern Social Science Quarterly for six years.

Professor Benson served in the United States Navy during World War II and served as a translator during the Japanese surrender. During the 1950s, the late George Lynn Cross, president of the university at the time, asked Benson to testify on behalf of the department before the state legislature when the legislature was investigating the university, and specifically the department, for sub- versive Communist activities. Benson's testimony as to why the department was teaching Marxism persuaded the legislature to end the investigation.

Oliver Benson was a visiting professor at Northwestern University, University of Texas, and University of Minnesota. At Northwestern in 1954-55, he pioneered the use of mathematics in political science research. The author of twelve books and over eighty articles, he served his university, his community, and his profession with distinction. He wrote in many areas, from international diplomacy to quantitative methods, and was one of the first political scientists to use computers to assist empirical research. As early as 1952, he presented a paper titled "Computer Simulation as a Research Policy." His 1969 text, Political Science Laboratory, is considered a classic in the field of research methods. The importance of his work was widely recognized throughout the profession.

Commenting on Benson's legacy, Samuel A. Kirkpatrick, former president of the University of Texas, San Antonio and a long-time Oklahoma faculty member, said, "Oliver Benson was in the leadership vanguard of a paradigm shift in his discipline of political science-a position that only a very few can lay claim to in any academic field. It was characterized by both new theories and new methodologies of inquiry and analysis that he shaped profoundly. Its impact was enduring for both teaching and research."

A respected teacher, Oliver Benson also wanted to recognize and assist the gifted students who came after him. Before his death, he established both an undergraduate paper award in his name and a scholarship to honor his late wife, June Benson, who served as Norman, Oklahoma's first and only woman mayor in 1957 and 1959. Together, they were pillars of the university community for over four decades.

Regents' Professor Emeritus Walter F. Scheffer, a former col- league, reflecting on Oliver Benson's personal qualities, remembered, "I have never known an occasion when Oliver showed less than tolerance, understanding, and great patience with each and every student who sought his help and guidance.... He was always trustworthy, cooperative and respectful of peers and students. His advice and counsel was consistently sought, even long after retirement, in departmental affairs and programs, as well as from individuals in, their professional pursuits. ... He enriched his department and the university community for all the years that he served it."

Oliver Benson is survived by his children, Dr. John Michael Benson of Bar Harbor, Maine, and Megan Kathleen Benson of Norman, Oklahoma; his six grandchildren, Kati Scheid and Laura Garber, Jeffrey Benson and David Benson, and Sara Doolittle and Marta Doolittle; and eight great-grandchildren.

Ronald M. Peters Jr. The University of Oklahoma

\section{Alfred G. Meyer}

Alfred G. Meyer, professor emeritus of political science at the University of Michigan, died at the age of 78 on April 22, 1998. Al had been on the Michigan faculty for 24 years, before retiring in June 1990. Even after his retirement, $\mathrm{Al}$ continued to teach seminars for first-year students and courses in the Residential College at the university. Prior to joining the department at Michigan, Al had served on the faculties at the University of Washington and Michigan State.

Al was born in Germany on February 5,1920 . He left Germany in 1939 , on a boat headed for the United States. The ship was turned back and he wound up in Amsterdam, where his brother still lives, but escaped to the United States in 1940. After arriving in the States, he enlisted in the army and served from 1941-45. He was awarded the Bronze Star.

Always eager to play the role of the maverick, the one who proudly 